\title{
Optimization of conditions to achieve high content of gamma amino butyric acid in germinated black rice, and changes in bioactivities
}

\author{
Chaiyavat CHAIYASUT ${ }^{1 *}$, Bhagavathi Sundaram SIVAMARUTHI ${ }^{1}$, Noppawat PENGKUMSRI ${ }^{1,2}$, Manee SAELEE ${ }^{1}$, \\ Periyanaina KESIKA ${ }^{1}$, Sasithorn SIRILUN ${ }^{1}$, Pranom FUKNGOEN ${ }^{1}$, Korawee JAMPATIP ${ }^{1}$, Suchanat KHONGTAN ${ }^{3}$, \\ Sartjin PEERAJAN ${ }^{3}$
}

\begin{abstract}
The present study estimated the optimum germination conditions to achieve high content of Gamma-amino butyric acid (GABA) and other phytochemicals in Thai black rice cultivar Kum Payao (BR). The Box-Behnken design of response surface methodology was employed to optimize the germination conditions. The changes in the GABA, phytochemical content, impact of salt, and temperature stress variation on phytochemical content, and stability of GABA were studied. The results showed that $12 \mathrm{~h}$ of soaking at $\mathrm{pH} 7$, followed by $36 \mathrm{~h}$ of germination was the optimum condition to achieve maximum GABA content $(0.2029 \mathrm{mg} / \mathrm{g}$ of germinated $\mathrm{BR}(\mathrm{GBR}))$. The temperature $\left(8\right.$ and $\left.30^{\circ} \mathrm{C}\right)$, and salt $(50-200 \mathrm{mM} \mathrm{NaCl})$ content affected the phytochemicals of GBR, especially GABA, and anthocyanins. Obviously, the antioxidant capability, and enzyme ( $\alpha$-amylase and $\alpha$-glucosidase) inhibiting nature of BR was significantly $(P<0.001)$ increased after germination. The storage of $\mathrm{GBR}$ at $4{ }^{\circ} \mathrm{C}$ significantly, preserved the GABA content ( $80 \%)$ for 45 days. Primarily, the current study revealed the changes in phytochemical content, and bioactivity of Thai black rice cr. Kum Payao during germination. More studies should be carried out on pharmacological benefits of GABA-rich GBR.
\end{abstract}

Keywords: germinated rice; gamma-amino butyric acid; antioxidant; stress; stability.

Practical Application: Optimization of germination conditions to produce GABA-rich germinated rice for pharmaceutical applications.

\section{Introduction}

Rice (Oryza sativa L.) is one of the widely consumed cereals food crops, especially in Asian countries. It is enriched with many phytochemicals, like phenolic acids, flavonoids, anthocyanins, tocols, and oryzanol. The color of the rice coat varies with anthocyanin content; based on the color, rice varieties are commonly classified as black, brown, and red rice (Pengkumsri et al., 2015a). It is well known that the rice phytochemicals have the ability to reduce the cholesterol absorption, and platelet aggregation (Patel \& Naik, 2004; Lerma-García et al., 2009). Black rice (BR) varieties are documented as an effective source of antioxidants and other health promoting compounds and are used in the treatment of oxidative stress related diseases and cancers (Salgado et al., 2010).

Thai rice cultivars are superior in terms of bio-functional compounds, and the extraction of active compounds from the rice bran (RB) of Chiang Mai Black rice, Mali Red rice, and Suphanburi-1 Brown rice were reported recently (Sompong et al., 2011; Pengkumsri et al., 2015a, b).The germination process promotes the phytochemical content of grains. Germinated rice is prepared by soaking them in water for a particular time, and at a specific temperature. The soaking time and temperature varies depending on the type of rice used. Excessive soaking of rice leads to microbial enrichment and fermentation (Bandara et al., 1991), whereas insufficient soaking does not support the augmentation of phytochemical content. The germination time of rice plays a critical role in the therapeutic property of germinated rice since it increases the bioactive compounds.

It is reported that germinated brown rice is enriched with minerals, vitamins, fiber, and other compounds like phytic acid, and ferulic acid (Hunt et al., 2002; Tian et al., 2004). It was reported that the germinated brown rice have many health benefits especially glucose, and cholesterol reducing properties (Hsu et al., 2008; Patil \& Khan, 2011). Roohinejad et al. (2010) reported that the germinated brown rice have a greater cardioprotective effect on hypercholesterolemic rats than non-germinated brown rice.

Gamma-amino butyric acid (GABA) is a non-protein amino acid, one of the well-studied inhibitory neurotransmitters that present in mammals, and plants. The environmental stress, and stimuli, like hypoxia, darkness, heat shock, and cold shock, and so on could elevate the synthesis of GABA (Bown et al., 2006). The soaking of rice in water for germination activates the GABA production. GABA content in rice was found to vary among rice varieties (Roohinejad et al., 2011).The impact of rice cultivar and 
germination process on GABA content in germinated brown rice were reported. The germination process causes a change in tocols, oryzanol content, and also decrease the amylose content (Cho \& Lim., 2016).

There is no substantial evidence about the effect of germination time and temperature on GABA, and other phytochemical content of Thai black rice cultivar (Chiang Mai Black rice). Thus, this study examined the effect of various soaking time, germination time, and $\mathrm{pH}$ of the water using Box-Behnken design (BBD) of the experiment, on the GABA content of GBR. BBD is a widely acceptable response surface methodology (RSM) to detect the optimum conditions for the desirable outcome with optimal values of selected influencing variables (Box \& Behnken, 1960; Woraharn et al., 2016).

The alterations in the total phenolic and anthocyanin content of GBR at optimum condition of GABA production was also investigated. Additionally, the study explored the impact of salinity, and temperature on bio-content, antioxidant ability of GBR, and the ability of GBR to inhibit the amylolytic enzymes ( $\alpha$-amylase and $\alpha$-glucosidase).

\section{Materials and methods}

\subsection{Sample collection and preparation}

The black rice cultivar Kum Payao (Oryza sativa L.) was obtained from Payao province, Thailand and dehydrated at $40^{\circ} \mathrm{C}$ for $48 \mathrm{~h}$ before extraction. The BR samples were subjected to $\gamma$-aminobutyric acid (GABA) extraction (by $4 \%$ acetic acid in $50 \%$ ethanol), phenolics and anthocyanins extraction (by $0.1 \mathrm{~N}$ $\mathrm{HCl}$ in ethanol, in the ratio of 15:85), and tocols extraction (by hexane).

\subsection{Extraction and analysis of GABA by High-Performance Liquid Chromatography (HPLC)}

The BR was extracted with $4 \%$ acetic acid in $50 \%$ ethanol solution by shaking at $150 \mathrm{rpm}$ (at room temperature (RT)) for $1 \mathrm{~h}$, and centrifuged at $6000 \mathrm{rpm}$ at RT for $20 \mathrm{~min}$, then the supernatant was collected. The obtained supernatant was subjected to evaporation at $50^{\circ} \mathrm{C}$ by vacuum evaporator (Rotavapor R-210, BUCHI) to acquire the concentrated extract. Then, the black rice extracts (BRE) was analyzed by high-performance liquid chromatography (HPLC) as detailed in the previous report (Woraharn et al., 2016).

\subsection{Extraction and analysis of phytochemicals}

The BR was extracted with $0.1 \mathrm{~N} \mathrm{HCl}$ in ethanol at the ratio of $15: 85$ by shaking at $150 \mathrm{rpm}$ (at RT) for $1 \mathrm{~h}$, and filtrated through $0.45 \mu \mathrm{m}$ membrane. The obtained supernatant was evaporated at $50{ }^{\circ} \mathrm{C}$ by vacuum evaporator to obtain the concentrated extract.

The total phenolic and anthocyanin content of the BR extract was analyzed by spectrophotometry and HPLC as detailed in the previous report, respectively. Total phenolic content was represented as mg of gallic acid equivalent (mg GAE), and the total anthocyanin content was stated as mg cyanidin chloride equivalent (mg CCE) per g of GBR (Pengkumsri et al., 2015a).
The level of common phenolic compounds such as protocatechuic acid, resorcinol, $p$-hydroxybenzoic acid, chlorogenic acid, caffeic acid, vanillic acid, syringic acid, $p$-coumaric acid, and benzoic acid in BR samples was determined by HPLC (Pengkumsri et al., 2015a).

The anthocyanins profile of the BR samples were studied by reversed-phase HPLC analysis. Both the concentration of glucoside (Delphinidin 3-glucoside, Cyanidin 3-glucoside, Peonidin 3-glucoside, Malvidin 3-glucoside), and aglycoside (Delphinidin chloride, Cyanidin chloride, Pelargonidin chloride, Peonidin chloride, and Malvidin chloride) form of the anthocyanins were determined (Pengkumsri et al., 2015a).

The tocols content (both tocotrienols and tocopherols) of BR samples were calculated by reversed-phase HPLC (Pengkumsri et al., 2015b). All the phytochemical analysis were performed as per the same conditions and instrumental setup described in our previous reports (Pengkumsri et al., 2015a, b). All the samples were measured in triplicate.

\subsection{Optimizing of germination condition}

The response surface method (RSM) was employed to optimize the multiple variants that affect the GABA content in BR. The Stat-Ease software (Design-Expert 10.0.0, Delaware, USA) was used for experimental design and statistical analysis. A three-factor with three-level of the Box-Behnken design was selected to evaluate the effect of the combination of three independent variables such as soaking time, soaking $\mathrm{pH}$, germination time, coded as $\mathrm{X} 1, \mathrm{X} 2$, and $\mathrm{X} 3$, respectively. The values were selected for the individual assessment of the impact of selected variables. The minimum and maximum values for soaking time, soaking $\mathrm{pH}$ and germination time were set as 1 and 24 h., 5 and 9, 12 and 36 h., respectively. The response values for GABA content were -1 (Lower), 0 (Middle), and +1 (Higher). The complete experimental scheme comprised of 20 experiments with five replicates of the center point. The Analysis of Variance (ANOVA) was used for data analysis and $p<0.05$ was considered as significant. The experimental data were established by quadratic model. Optimum parameters were defined by the Design-Expert software version 10.0.0. The procedure of the RSM design and analysis can be found in our previous reports (Woraharn et al., 2016; Sirilun et al., 2016). The RSM plots were generated using Statistica software trial version (Dell Inc. USA). The GABA content, Phenolics content and anthocyanins content in GBR with different experimental setup was measured.

\subsection{Assessment of salt and cold stress on phytochemical content of $B R$}

The salt $(\mathrm{NaCl}$ at the concentration of $50,100,200 \mathrm{mM})$ and cold $\left(8^{\circ} \mathrm{C}\right.$, and $\left.\mathrm{RT}\left(\sim 30^{\circ} \mathrm{C}\right)\right)$ stress during the germination process and influence on the phytochemical content of $\mathrm{BR}$ was evaluated with optimum soaking period, $\mathrm{pH}$, and germination temperature (soaking in water $\mathrm{pH} 7.0$ for $12 \mathrm{~h}$. and germinated at $40{ }^{\circ} \mathrm{C}$ for $36 \mathrm{~h}$ ). The GABA content, tocols content, phenolics content, and anthocyanins content of GBR 
was studied by spectrophotometry and HPLC techniques as described above.

\subsection{Assessment of antioxidant capacity}

Antioxidant capacity of non-germinated and germinated BR extracts such as GABA, phenolics, anthocyanins, and tocols were assessed by 1, 1-diphenyl-2-picryl-hydrazil (DPPH), 2, 2'-azino-bis-3-ethylbenzthiazoline-6-sulphonic acid (ABTS), ferric-reducing antioxidant power (FRAP), and inhibition of lipid peroxidation (LPO) assays as described earlier (Pengkumsri et al., 2015a, b).

\subsection{Analysis of amylolytic enzymes}

The 3, 5-dinitrosalicylic acid (DNS) method was used to determine the $\alpha$-amylase and $\alpha$-glucosidase activity (Subramanian et al., 2008). The a-amylase inhibition was measured as following, Briefly, $250 \mu \mathrm{L}$ of BR extracts and $500 \mu \mathrm{L}$ of $25 \mathrm{mM}$ sodium phosphate buffer $\mathrm{pH} 7.0$ containing 5 unit/mL of a-amylase (Cat. No. 10080, Sigma-Aldrich Chemical Co, Steinheim, Germany) was mixed and incubated at $25{ }^{\circ} \mathrm{C}$ for $10 \mathrm{~min}$. After incubation, $25 \mu \mathrm{l}$ of $0.5 \%$ starch solution in $20 \mathrm{mM}$ sodium phosphate buffer, $\mathrm{pH} 7.0$ was added and incubated at $25^{\circ} \mathrm{C}$ for $10 \mathrm{~min}$. Then, $500 \mu \mathrm{l}$ of DNS solution (Cat. No. D 0550, Sigma-Aldrich Chemical Co, U.S.A) was added and kept in boiling water bath for $15 \mathrm{~min}$ and cooled to RT. The absorbance was measured at $540 \mathrm{~nm}$.

The $\alpha$-glucosidase inhibition was evaluated by the following procedure, $5 \mathrm{U} / \mathrm{mL}$ of $\alpha$-glucosidase (Cat. No. G 5003, Sigma-Aldrich Chemical Co, U.S.A) was dissolved in $0.1 \mathrm{mM}$ phosphate buffer. About $100 \mu \mathrm{l}$ of $5 \mathrm{U} / \mathrm{mL}$ of $\alpha$-glucosidase and $50 \mu \mathrm{L}$ of BRE samples were incubated at $37^{\circ} \mathrm{C}$ for $10 \mathrm{~min}$. After incubation, $500 \mu \mathrm{L}$ of $0.1 \mathrm{M}$ sucrose solution in $0.1 \mathrm{mM}$ phosphate buffer, $\mathrm{pH} 7.0$ was added and incubated at $37^{\circ} \mathrm{C}$ for $60 \mathrm{~min}$. Then, $1,000 \mu \mathrm{L}$ of DNS solution was added and kept in boiling water bath for $10 \mathrm{~min}$ and cooled to RT. The absorbance was measured at $540 \mathrm{~nm}$. The samples were analyzed in triplicates.

\subsection{Evaluation of stability of $G A B A$ in $G B R$}

The test condition was set as per the International Council for Harmonization (ICH) Q1A (R2) guidance, Center for Drug Evaluation and Research, U.S. Department of Health and Human Services Food and Drug Administration. The GBR samples were stored at 4,25 , and $40{ }^{\circ} \mathrm{C}$ for 90 days. The germinated black rice extract (GBRE) was collected after $0,3,7,15,30,45,60,75,90$ days of storage and the GABA content was assessed.

\subsection{Statistical analysis}

The quantity of the biochemical and their antioxidant activity was performed in independent triplicates data are reported as mean \pm SD. Analysis of variance (ANOVA) was performed to assess the differences in antioxidant activities. The Least Significant Difference (LSD) post hoc test determined significant differences, at the $95 \%$ confidential level $(p<0.05)$ using statistical SPSS software version 16 (Chicago, SPSS Inc, USA).

\section{Results and discussion}

\subsection{Phytochemical content of black rice}

The BRE was evaluated for phenolic, anthocyanin, tocols, and GABA content. About 16.77 \pm 0.85, $23.42 \pm 1.78,126.2 \pm 6.32$, and $54.14 \pm 2.72 \mu \mathrm{g} / \mathrm{g}$ of rice of protocatechuic acid, chlorogenic acid, vanillic acid, and $p$-coumaric acid were recorded in BRE. Anthocyanins (cyanidin 3-glucoside $(8.12 \pm 0.42 \mathrm{mg} / \mathrm{g}$ of rice), and peonidin 3 -glucoside $(276 \pm 18.34 \mathrm{mg} / \mathrm{g}$ of rice $))$, and Tocols ( $\delta$-tocotrienol $(5.01 \pm 0.03 \mu \mathrm{g} / \mathrm{g}$ of rice), $\gamma$-tocotrienol $(11.05 \pm 0.06 \mu \mathrm{g} / \mathrm{g}$ of rice) $)$ were detected in BRE. BRE contained $4.4 \pm 0.23 \mu \mathrm{g} / \mathrm{g}$ of rice of GABA (Table 1A of Appendix A).

\subsection{Optimum condition for GABA production}

The present study emphasized on the improvement of GABA content of BR by germination. It is known that several factors influence the GABA formation in germinated rice, particularly, soaking time, soaking $\mathrm{pH}$, and germination time. The $\mathrm{BBD}$ was employed for the detection of optimum condition for GABA production. Three different soaking times (1, 12, and $24 \mathrm{~h}$ ), soaking $\mathrm{pH}(5,7,9)$, and germination time $(12,24,36 \mathrm{~h})$ were selected and 20 independent experiments were performed, with all possible combinations as per the BBD. The results indicated that $12 \mathrm{~h}$ of soaking at $\mathrm{pH} \mathrm{7,followed} \mathrm{by} 36 \mathrm{~h}$ of germination was the optimum condition to achieve maximum GABA content of $0.2029 \mathrm{mg} / \mathrm{g}$ of GBR (Table 2A).

Regression equation, model $P$ value, lack-of-fit $P$ value test and coefficient of determination $\left(\mathrm{R}^{2}\right)$ were evaluated for GABA production (Table 3A and Equation 1). The estimated values and $p$ values were tabulated, and the statistical analysis (by design expert) proved that the acceptability of the software derived a quadratic equation for GABA content in GBR. The lowest residual sum of square (0.0014) and lack of fit $(P=0.2048)$ advocated that the model equation was appropriate for the estimation of GABA content in GBR. The RSM plots were generated using Statistica software, and all independent variables such as soaking times, soaking $\mathrm{pH}$, and germination time influenced the production of GABA content of GBR (Table 3A, Figure 1).

\subsection{Phytochemical content of Germinated Black Rice (GBR)}

At optimum condition, BR was germinated and was extracted. Then GBR extract (GBRE) was further evaluated for phenolic, anthocyanin, tocols, and GABA content. About $31.06 \pm 1.58,43.38 \pm 2.21,133.70 \pm 6.82$, and $90.27 \pm 4.60 \mu \mathrm{g} / \mathrm{g}$ of rice of protocatechuic acid, chlorogenic acid, vanillic acid, and $p$-coumaric acid were recorded in GBRE. Anthocyanins (cyanidin 3-glucoside $(15.03 \pm 0.77 \mathrm{mg} / \mathrm{g}$ of rice), and peonidin 3 -glucoside $(311.11 \pm 15.87 \mathrm{mg} / \mathrm{g}$ of rice $)$ ), and Tocols ( $\delta$-tocotrienol $(5.21 \pm 0.27 \mu \mathrm{g} / \mathrm{g}$ of rice), $\gamma$-tocotrienol $(11.82 \pm 0.60 \mu \mathrm{g} / \mathrm{g}$ of rice)) were detected in GBRE. GBRE was detected with $202.90 \pm 4.35 \mu \mathrm{g} / \mathrm{g}$ of rice of GABA (Table 1A).

After germination all the validated phytochemical content, except tocols $(P=0.163-0.696)$, and cyanidin 3-glucoside $(P=0.540)$, were increased significantly than in non-germinated rice. Notably, the content of GABA in BRE was increased from $4.4 \pm 0.23$ to $82.34 \pm 4.35 \pm 0.23 \mu \mathrm{g} / \mathrm{g}$ of rice of GABA during 
(a)

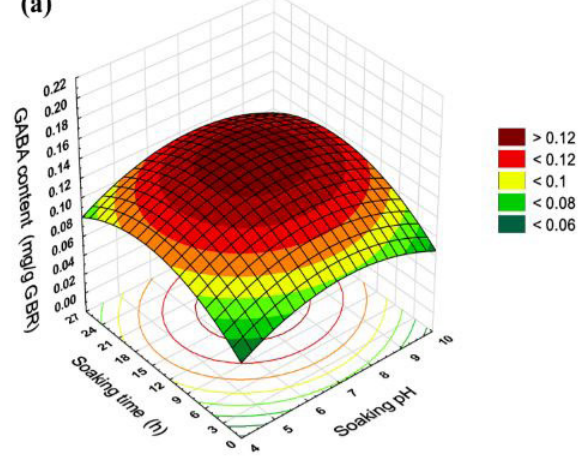

(b)

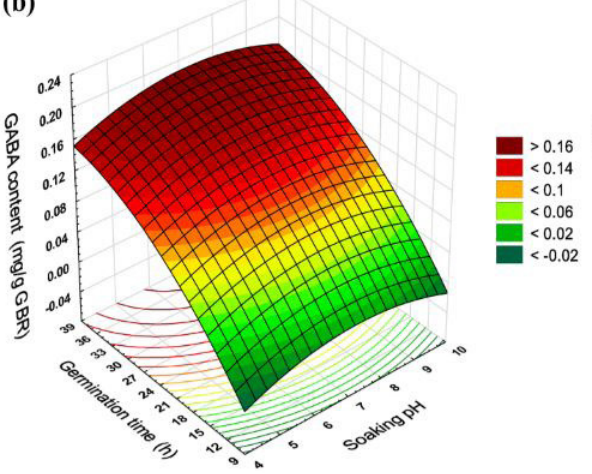

(c)

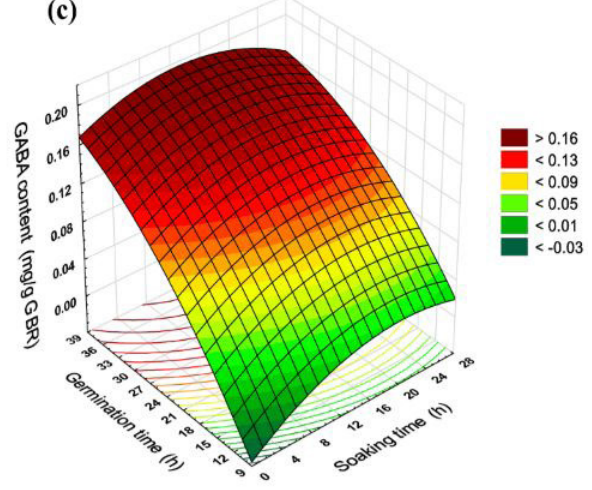

Figure 1. Response surface for the effect of soaking time (h), soaking $\mathrm{pH}$ and germination time (h) GABA concentration (mg/g of GBR). (a) effect of concentration of soaking time (h), and soaking $\mathrm{pH}$ on GABA content, (b) effect of germination time (h) and soaking $\mathrm{pH}$ on GABA content and (c) effect of germination time (h) and soaking time (h) on GABA content.

germination process at the optimum condition which indicated that the condition ( $12 \mathrm{~h}$ of soaking at $\mathrm{pH} 7$, followed by $36 \mathrm{~h}$ of germination) derived from BBD and RSM was best for the germination of tested $\mathrm{BR}$ cultivar in terms of phytochemicals content, especially GABA $(P=0.000)$ (Table $1 \mathrm{~A})$.

The influences of soaking and germination conditions on phenolic, flavonoid, GABA concentration and free radical scavenging activity of Thai rice cultivars namely, Luang Thong, Jek Chuey1, Khao Dawk Mali 105, Prathum Thani 1, and Pong Ell were described. The researcher also reported that about $24 \mathrm{~h}$ of germination process increased the GABA content of rice up to 4 fold, and besides there was no association between GABA, phenolic and flavonoid contents (Jirapa et al., 2016). It is known that the variations in the GABA content depend on the rice varieties. MRQ74, one of the black rice cultivars, recorded with $0.44 \mathrm{mg} / \mathrm{g}$ of rice of GABA, whereas another black rice cultivar, namely, MR232, showed only $0.03 \mathrm{mg} / \mathrm{g}$ of rice of GABA (Roohinejad et al., 2011). Soaking and gas treatment enhanced the GABA content in brown rice $(24.9 \mathrm{mg} / 100 \mathrm{~g}$ of rice), and also ethanol treatment removed the microbial load, which was generated during soaking of rice without affecting the GABA content (Komatsuzaki et al., 2007).

The total phenolic acid content (mg GAE/g extract), ABTS scavenging activity (mg TEAC/g extract), and DPPH free radical scavenging activity of Malaysian germinated brown rice (MR220) was $12.01 \pm 0.2,6.31 \pm 0.57$, and $5.27 \pm 0.17$, respectively.

While, non-germinated rice showed $3.17 \pm 1.68,2.67 \pm 0.24$, and $6.82 \pm 0.23$ of total phenolic content, ABTS, and DPPH activity, respectively (Imam et al., 2012). The phenolic and flavonoid contents increased in germinated jasmine rice (KDML105) (Phattayakorn et al., 2016). The present study also highlighted the significant increase in phenolic compounds, anthocyanins, tocols, and GABA contents in GBR compared to non-germinated BR. Notably, about 46.1 fold increase in GABA concentration was observed in GBR $(202.9 \pm 4.35 \mu \mathrm{g} / \mathrm{g}$ of rice) than $\mathrm{BR}(4.4 \pm 0.23 \mu \mathrm{g} / \mathrm{g}$ of rice $)$ at optimum condition derived from BBD (Table 1A).
The total phenolic acid content (mg GAE/g extract), ABTS scavenging activity (mg TEAC/g extract), and DPPH free radical scavenging activity of Malaysian germinated brown rice (MR220) were $12.01 \pm 0.2,6.31 \pm 0.57$, and $5.27 \pm 0.17$, respectively. While, non-germinated rice showed $3.17 \pm 1.68$, $2.67 \pm 0.24$, and $6.82 \pm 0.23$ of total phenolic content, ABTS, and DPPH activity, respectively (Imam et al., 2012). The phenolic and flavonoid content was increased in germinated jasmine rice (KDML105) (Phattayakorn et al., 2016).

The present study also highlighted the significant increase in phenolic compounds, anthocyanins, tocols, and GABA contents in GBR compared to non-germinated BR. Notably, about 46.1 fold increase in GABA concentration was observed in GBR $(202.9 \pm 4.35 \mu \mathrm{g} / \mathrm{g}$ of rice $)$ than BR $(4.4 \pm 0.23 \mu \mathrm{g} / \mathrm{g}$ of rice) at optimum condition derived from $\mathrm{BBD}$ (Table 1A).

\subsection{Changes in the phytochemical content of GBR during stress condition}

The variations in the phytochemical content of GBR during salt and temperature stress were evaluated. Three different concentrations of $\mathrm{NaCl}(50,100$, and $200 \mathrm{mM})$, and two different temperatures $\left(8\right.$, and $\left.30^{\circ} \mathrm{C}\right)$ were used with four different germination time $(12,24,36$, and $48 \mathrm{~h})$. After the germination of BR at specific conditions, GBRE was prepared to assess the total phenolic, tocols, anthocyanins, and GABA content. The concentration of the phytochemicals has been increased significantly in the presence of $50 \mathrm{mM}$ of $\mathrm{NaCl}$ regardless of duration, compared to non-germinated rice extract (control). $200 \mathrm{mM}$ of $\mathrm{NaCl}$ significantly affected the $\gamma$-tocotrienol $(\mathrm{P}=0.009)$, GABA $(P=0.001)$, and anthocyanins $(P=0.044)$ content compared to $50 \mathrm{mM}$ groups (Figure 1A, of Appendix A).

The influence of temperature on phytochemical content enriched in GBR was studied. All the phytochemicals were significantly increased in both 8 , and $30^{\circ} \mathrm{C}$ groups than control (non-germinated rice extract). There were no significant differences observed in the phenolic acid content of GBR, germinated at 8 , and $30^{\circ} \mathrm{C}$ (Figure $2 \mathrm{~A}(\mathrm{a})$ ). The tocols content was altered in GBR grown at $30^{\circ} \mathrm{C}$ for 36 , and $48 \mathrm{~h}$ than $8^{\circ} \mathrm{C}$ for $36 \mathrm{~h}$. In detail, 
$\delta$-tocotrienol content was significantly increased in $30^{\circ} \mathrm{C}$ for 36 , and $48 \mathrm{~h}$ groups $(P=0.000)$. But $\gamma$-tocotrienol concentration was decreased in $30^{\circ} \mathrm{C} / 36 \mathrm{~h}$ group and increased in $30^{\circ} \mathrm{C} / 48 \mathrm{~h}$ group, significantly $(P=0.000)$ (Figure $2 \mathrm{~A}(\mathrm{~b}))$. The GABA content was significantly reduced in $30^{\circ} \mathrm{C} / 24 \mathrm{~h}(P=0.017)$, and $30^{\circ} \mathrm{C} / 48 \mathrm{~h}(P=0.007)$, groups. Likely, in all the conditions GABA concentration was increased than control (Figure $2 \mathrm{~A}(\mathrm{c})$ )). The concentration of anthocyanins was decreased at $30^{\circ} \mathrm{C}$, except in $30^{\circ} \mathrm{C} / 36$ h group $(P=0.000)$ (Figure $2 \mathrm{~A}(\mathrm{~d})$ ).

Umnajkitikorn et al. (2013) reported that the presence of salt $(150 \mathrm{mM} \mathrm{NaCl})$ enhanced the free radical scavenging ability of rice (cultivar Kum Doi Saket). Several studies reported the improvement of total phenolic, anthocyanins, and flavonoids content in Thai rice varieties during germination under the salinity (60-200 mM NaCl) (Chutipaijit et al., 2009, 2011; Daiponmak et al., 2010; Ghosh et al., 2011). The germination of cold sensitive rice seeds at $17^{\circ} \mathrm{C}$ improved the antioxidant property of rice seedlings, especially lipid peroxidation, and superoxide dismutase activity, and further facilitated the accumulation of plant hormone gibberellic acid, which diminished the impact of cold stress (Grohs et al., 2016). The brown rice (cultivar Khao Hom Dam Sukhothai 2) germinated at $35 \pm 0.5^{\circ} \mathrm{C}$ exhibited the superior antioxidant property than the rice germinated at $30 \pm 0.5^{\circ} \mathrm{C}$ (Pitiwiwattanakul et al., 2011).

The results of the present study, altogether, indicated that the salt concentration and temperature does not seriously affect the phytochemical content of GBR, but the duration played a critical role in the stability of the rice phytochemicals (Figure 1A and 2A).

\subsection{Changes in the bioactivity of black rice}

The GBRE was prepared from BR germinated at optimum condition (12 h of soaking at $\mathrm{pH} 7$, followed by $36 \mathrm{~h}$ of germination), and studied the variations in antioxidant capacity, and enzyme ( $\alpha$-glucosidase, and $\alpha$-amylase) inhibiting property of BR upon germination. The in vitro antioxidant models, ABTS, DPPH, FRAP, and lipid peroxidation tests were performed with phenolic, anthocyanins, GABA, and tocols extracts of GBR. In ABTS, DPPH, and lipid peroxidation assays, phenolic and anthocyanin extracts showed significant improvement in the antioxidant capacity of GBR regarding trolox equivalence than non-germinated group ( $\mathrm{BG}=$ Before Germination), significantly $(P=0.000)$, while in FRAP assay no significant changes were observed. The GABA, and tocols extracts were not changed in ABTS $(P=0.988, P=0.900$, respectively), DPPH $(P=0.955$, $P=0.652$, respectively), and lipid peroxidation $(P=0.647$, $P=0.283$, respectively) assays, whereas, significant $(P=0.000)$ increase was observed in FRAP assay (Figure 2). The percentage of enzyme inhibition was increased in GBR extracts, significantly $(P=0.000)$. The $\alpha$-amylase inhibiting property of phenolics, anthocyanins, GABA, and tocols was increased from 41.22 \pm 2.41 , $41.22 \pm 2.40,48.45 \pm 2.77$, and $21.06 \pm 2.08$ to $71.80 \pm 2.75,77.09$ $\pm 2.53,78.84 \pm 2.45$, and $47.13 \pm 1.87 \%$ of inhibition/ $\mathrm{mg}$ of extracts, respectively (Figure 3A (a)). Likewise, The $\alpha$ - glucosidase inhibiting property of phenolics, anthocyanins, GABA, and tocols was increased from $64.28 \pm 2.51,64.42 \pm 2.70,63.10 \pm$ 1.71 , and $63.62 \pm 1.35$ to $81.44 \pm 2.05,80.84 \pm 2.23,76.40 \pm 2.01$, and $76.59 \pm 1.33 \%$ of inhibition/mg of extracts, respectively (Figure 3A (b)). (a)

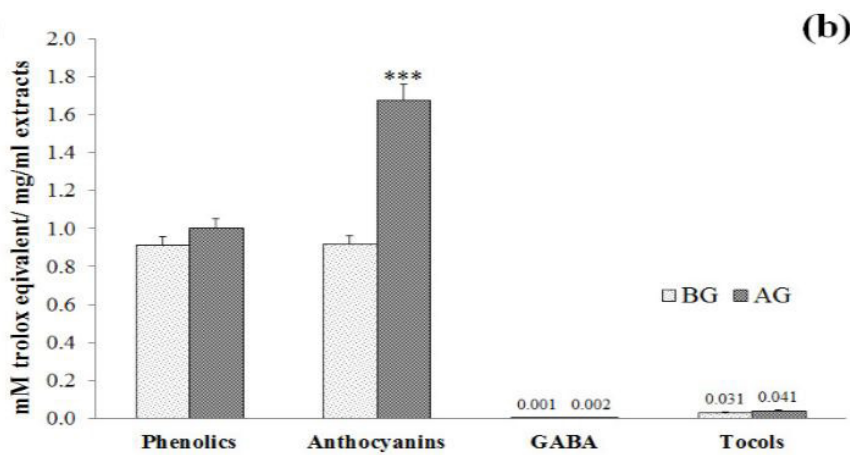

(c)

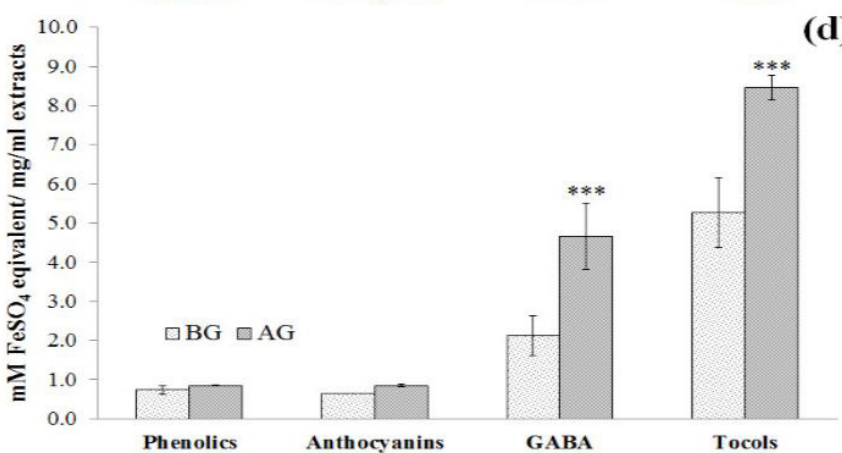

(b)

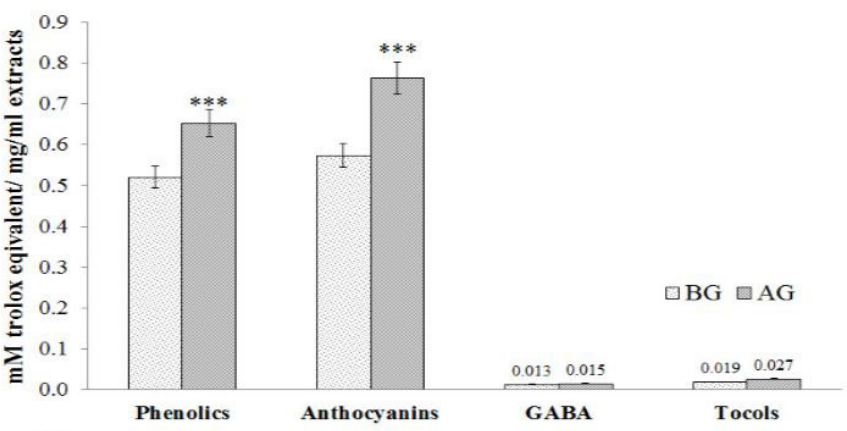

d)

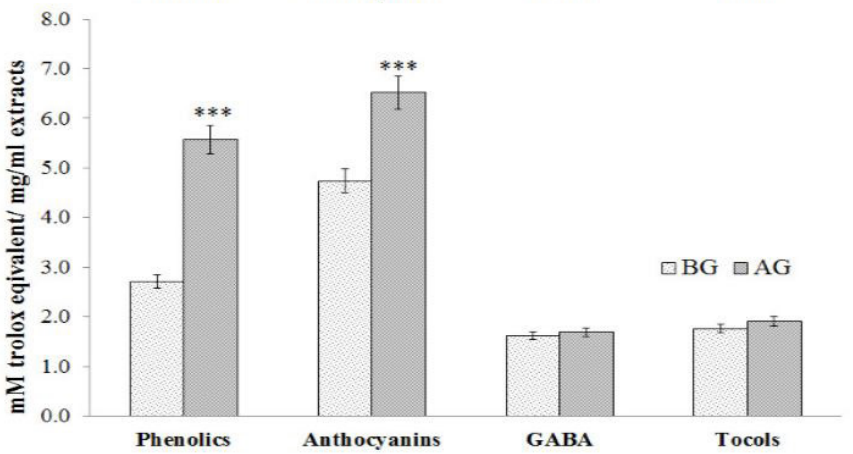

Figure 2. The changes in the antioxidant capacity of black rice. (a) ABTS (b) DPPH (c) FRAP (d) Lipid peroxidation assay. The significant changes $\left.{ }^{* * *} P \leq 0.001\right)$ were calculated by compared with non-germinated rice. BG: Before germination; AG: After germination. 
The germination improved the free radical scavenging ability of several Thai rice varieties (Daiponmak et al., 2010; Chutipaijit et al., 2009, 2011; Ghosh et al., 2011; Umnajkitikorn et al., 2013; Yodpitak et al., 2013). The study results also clearly indicated that germination procedure increased the bioactivities of $\mathrm{BR}$ phytochemicals (Figure 3A).

\subsection{Stability of $G A B A$ content of $G B R$}

The fundamental rationale of the present study was to increase the GABA concentration and investigate the impact of salt, and temperature on GABA content, and stability of the GABA in GBR. Thus, the stability assessments were performed as per the ICH- Q1A (R2) guidance and validated only the GABA content in GBR. The GBR samples were stored at 4,25 , and $40^{\circ} \mathrm{C}$ for 90 days, and the GABA content was assessed with constant intervals. About 33.24\% of degradation of GABA was recorded at $4{ }^{\circ} \mathrm{C}$ on the $90^{\text {th }}$ day of the experiment, whereas 68.06 , and $98.50 \%$ of GABA degradation was noted at 25 , and $40^{\circ} \mathrm{C}$ on the $90^{\text {th }}$ day, respectively. More than $50 \%$ of the GABA degradation (53.73\%) occurred within three days of storage of GBR at $40{ }^{\circ} \mathrm{C}$ (Figure 3A (c)). The stability study revealed that storage of GBR at $4{ }^{\circ} \mathrm{C}$, significantly, preserved the GABA.

\section{Conclusions}

The optimum conditions to achieve maximum GABA and other phytochemicals in GBR (cultivar Kum Payao) was $12 \mathrm{~h}$ of soaking at $\mathrm{pH} 7$, followed by $36 \mathrm{~h}$ of germination. $\alpha$-glucosidase, and the $\alpha$-amylase inhibiting property were increased in GBR. The presence of salt, at the concentration up to $100 \mathrm{mM}$ of $\mathrm{NaCl}$, did not significantly affect the phytochemical content of GBR, whereas, temperature $\left(30^{\circ} \mathrm{C}\right)$ influenced the chemical nature of GBR. The stability study revealed that storage of GBR at $4{ }^{\circ} \mathrm{C}$, significantly protects the nutritional value regarding GABA. Further studies on pharmacological benefits of GABA-rich GBR are under way, especially in metabolic disorders.

\section{Acknowledgements}

We gratefully acknowledge the National Research University - Chiang Mai University (NRU - CMU) and National Research University - Office of Higher Education Commission (NRU - OHEC), Ministry of Education, Thailand and Chiang Mai University for the financial supports. We wish to acknowledge the Faculty of Pharmacy, Chiang Mai University, Chiang Mai, Thailand for the necessary provision.

\section{References}

Bandara, J. M., Vithanege, A. K., \& Bean, G. A. (1991). Effect of parboiling and bran removal on aflatoxin levels in Sri Lankan rice. Mycopathologia, 115(1), 31-35. PMid:1922267. http://dx.doi. org/10.1007/BF00436418.

Bown, A. W., Macgregor, K. B., \& Shelp, B. J. (2006). Gammaaminobutyrate: Defense against invertebrate pests? Trends in Plant Science, 11(9), 424-427. PMid:16890474. http://dx.doi.org/10.1016/j. tplants.2006.07.002.
Box, G. P., \& Behnken, D. W. (1960). Some new three level designs for the study of quantitative variables. Technometrics, 2(4), 455-475. http://dx.doi.org/10.1080/00401706.1960.10489912.

Cho, D. H., \& Lim, S. T. (2016). Germinated brown rice and its biofunctional compounds. Food Chemistry, 196, 259-271. PMid:26593491. http://dx.doi.org/10.1016/j.foodchem.2015.09.025.

Chutipaijit, S., Cha-um, S., \& Sompornpailin, K. (2009). Differential accumulations of proline and flvonoids in Indica rice varieties against salinity. Pakistan Journal of Botany, 41(5), 2497-2506.

Chutipaijit, S., Cha-um, S., \& Sompornpailin, K. (2011). High contents of proline and anthocyanin increase protective response to salinity in 'Oryza sativa' L. spp. 'indica'. Australian Journal of Crop Science, 5(10), 1191-1198.

Daiponmak, W., Theerakulpisut, P., Thanonkao, P., Vanavichit, A., \& Prathepha, P. (2010). Changes of anthocyanin cyanidin-3-glucoside content and antioxidant activity in Thai rice varieties under salinity stress. ScienceAsia, 36(4), 286-291. http://dx.doi.org/10.2306/ scienceasia1513-1874.2010.36.286.

Ghosh, S. K., Missra, A., \& Gilmour, D. S. (2011). Negative elongation factor accelerates the rate at which heat shock genes are shut off by facilitating dissociation of heat shock factor. Molecular and Cellular Biology, 31(20), 4232-4243. PMid:21859888. http://dx.doi. org/10.1128/MCB.05930-11.

Grohs, M., Marchesan, E., Roso, R., \& Moraes, B. S. (2016). Attenuation of low-temperature stress in rice seedlings. Pesquisa Agropecuária Tropical, 46(2), 197-205. http://dx.doi.org/10.1590/1983-40632016v4640436.

Hsu, T. F., Kise, M., Wang, M. F., Ito, Y., Yang, M. D., Aoto, H., Yoshihara, R., Yokoyama, J., Kunii, D., \& Yamamoto, S. (2008). Effects of pregerminated brown rice on blood glucose and lipid levels in freeliving patients with impaired fasting glucose or type 2 diabetes. Journal of Nutritional Science and Vitaminology, 54(2), 163-168. PMid:18490847. http://dx.doi.org/10.3177/jnsv.54.163.

Hunt, J. R., Johnson, L. K., \& Juliano, B. O. (2002). Bioavailability of zinc from cooked philippine milled, undermilled, and brown rice, as assessed in rats by using growth, bone zinc, and zinc- 65 retention. Journal of Agricultural and Food Chemistry, 50(18), 5229-5235. PMid:12188635. http://dx.doi.org/10.1021/jf020222b.

Imam, M. U., Musa, S. N., Azmi, N. H., \& Ismail, M. (2012). Effects of white rice, brown rice and germinated brown rice on antioxidant status of type 2 diabetic rats. International Journal of Molecular Sciences, 13(10), 12952-12969. PMid:23202932. http://dx.doi. org/10.3390/ijms131012952.

Jirapa, K., Jarae, Y., Phanee, R., \& Jirasak, K. (2016). Changes of bioactive components in germinated paddy rice (Oryza sativa L.). International Food Research Journal, 23(1), 229-236.

Komatsuzaki, N., Tsukahara, K., Toyoshima, H., Suzuki, T., Shimizu, N., \& Kimura, T. (2007). Effect of soaking and gaseous treatment on GABA content in germinated brown rice. Journal of Food Engineering, 78(2), 556-560. http://dx.doi.org/10.1016/j.jfoodeng.2005.10.036.

Lerma-García, M. J., Herrero-Martinez, J. M., Simo-Alfonso, E. F., Mendonca, C. R. B., \& Ramis-Ramos, G. (2009). Composition, industrial processing and applications of rice bran $\gamma$-oryzanol. Food Chemistry, 115(2), 389-404. http://dx.doi.org/10.1016/j. foodchem.2009.01.063.

Patel, M., \& Naik, S. N. (2004). Gamma-oryzanol from rice bran oil: a review. Journal of Scientific and Industrial Research, 63, 569-578.

Patil, S. B., \& Khan, M. K. (2011). Germinated brown rice as a value added rice product: A review. Journal of Food Science and Technology, 48(6), 661-667. PMid:23572802. http://dx.doi.org/10.1007/s13197011-0232-4. 
Pengkumsri, N., Chaiyasut, C., Saenjum, C., Sirilun, S., Peerajan, S., Suwannalert, P., Sirisattha, S., \& Sivamaruthi, B. S. (2015a). Physicochemical and antioxidative properties of black, brown and red rice varieties of northern Thailand. Food Science and Technology, 35(2), 331-338. http://dx.doi.org/10.1590/1678-457X.6573.

Pengkumsri, N., Chaiyasut, C., Sivamaruthi, B. S., Saenjum, C., Sirilun, S., Peerajan, S., Suwannalert, P., Sirisattha, S., Chaiyasut, K., \& Kesika, P. (2015b). The influence of extraction methods on composition and antioxidant properties of rice bran oil. Food Science and Technology, 35(3), 493-501. http://dx.doi.org/10.1590/1678-457X.6730.

Phattayakorn, K., Pajanyor, P., Wongtecha, S., Prommakool, A., \& Saveboworn, W. (2016). Effect of germination on total phenolic content and antioxidant properties of 'Hang' rice. International Food Research Journal, 23(1), 406-409.

Pitiwiwattanakul, V., Phimphilai, S., Nuglor, S., \& Chiyasut, C. (2011). Effects of germinating conditions on antioxidant properties, total polyphenol and phytate contents in quick-cooking husked Hom Dam Sukhothai 2 rice. Asian Journal of Food and Agro-Industry, 4(05), 297-305.

Roohinejad, S., Omidizadeh, A., Mirhosseini, H., Saari, N., Mustafa, S., Mohd Yusof, R., Meor Hussin, A. S., Hamid, A., \& Abd Manap, M. Y. (2010). Effect of pre-germination time of brown rice on serum cholesterol levels of hypercholesterolaemic rats. Journal of the Science of Food and Agriculture, 90(2), 245-251. PMid:20355038. http:// dx.doi.org/10.1002/jsfa.3803.

Roohinejad, S., Omidizadeh, A., Mirhosseini, H., Saari, N., Mustafa, S., Meor Hussin, A. S., Hamid, A., \& Abd Manap, M. Y. (2011). Effect of pre-germination time on amino acid profile and gamma amino butyric acid (GABA) contents in different varieties of Malaysian brown rice. International Journal of Food Properties, 14(6), 13861399. http://dx.doi.org/10.1080/10942911003687207.

Salgado, J. M., Oliveira, A. G., Mansi, D. N., Donado-Pestana, C. M., Bastos, C. R., \& Marcondes, F. K. (2010). The role of black rice (Oryza sativa L.) in the control of hypercholesterolemia in rats. Journal of Medicinal Food, 13(6), 1355-1362. PMid:21091249. http://dx.doi. org/10.1089/jmf.2009.0246.

Sirilun, S., Chaiyasut, C., Pengkumsri, N., Peerajan, S., Chaiyasut, K., Suwannalert, P., \& Sivamaruthi, B. S. (2016). Screening and characterization of $\beta$-glucosidase production by Saccharomyces cerevisiae. Journal of Applied Pharmaceutical Science, 6(5), 29-35.

Sompong, R., Siebenhandl-Ehn, S., Linsberger-Martin, G., \& Berghofer, E. (2011). Physicochemical and antioxidative properties of red and black rice varieties from Thailand, China and Sri Lanka. Food Chemistry, 124(1), 132-140. http://dx.doi.org/10.1016/j.foodchem.2010.05.115.

Subramanian, R., Asmawi, M. Z., \& Sadikun, A. (2008). In vitro a-glucosidase and a-amylase enzyme inhibitory effects of Andrographis paniculata extract and andrographolide. Acta Biochimica Polonica, 55(2), 391-398. PMid:18511986.

Tian, S., Nakamura, K., \& Kayahara, H. (2004). Analysis of phenolic compounds in white rice, brown rice, and germinated brown rice. Journal of Agricultural and Food Chemistry, 52(15), 4808-4813. PMid:15264919. http://dx.doi.org/10.1021/jf049446f.

Umnajkitikorn, K., Faiyue, B., \& Saengnil, K. (2013). Enhancing antioxidant properties of germinated Thai rice (Oryza sativa L.) cv. Kum Doi Saket with salinity. Rice Research, 1(1), 103. http://dx.doi. org/10.4172/jrr.1000103.

Woraharn, S., Lailerd, N., Sivamaruthi, B. S., Wangcharoen, W., Sirisattha, S., Peerajan, S., \& Chaiyasut, C. (2016). Evaluation of factors that influence the L-glutamic and $\gamma$-aminobutyric acid production during Hericium erinaceus fermentation by lactic acid bacteria. CyTA - Journal of Food, 14(1), 47-54. http://dx.doi.org/10.1080/19 476337.2015.1042525.

Yodpitak, S., Sookwong, P., Akkaravessapong, P., \& Wongpornchai, S. (2013). Changes in antioxidant activity and antioxidative compounds of brown rice after pre-germination. Journal of Food and Nutrition Research, 1(6), 132-137. http://dx.doi.org/10.12691/jfnr-1-6-4. 
Appendix A. Supplementary Data.

Table 1A. Changes in the major phytochemical composition of Black rice during germination.

\begin{tabular}{|c|c|c|c|}
\hline \multirow{2}{*}{ S. No. } & \multirow{2}{*}{ Phytochemicals } & \multicolumn{2}{|c|}{ Concentration/g of Rice (Mean \pm SD) } \\
\hline & & Before germination & After germination \\
\hline \multirow[t]{5}{*}{1.} & Phenolic compounds & & \\
\hline & Protocatechuic acid & $16.77 \pm 0.85 \mu \mathrm{g}$ & $31.06 \pm 1.58 \mu g^{* *}$ \\
\hline & Chlorogenic acid & $23.42 \pm 1.78 \mu \mathrm{g}$ & $43.38 \pm 2.21 \mu \mathrm{g}^{* * *}$ \\
\hline & Vanillic acid & $126.2 \pm 6.32 \mu \mathrm{g}$ & $133.70 \pm 6.82 \mu g^{*}$ \\
\hline & $p$-coumaric acid & $54.14 \pm 2.72 \mu \mathrm{g}$ & $90.27 \pm 4.60 \mu \mathrm{g}^{\star * *}$ \\
\hline \multirow[t]{3}{*}{2.} & Anthocyanins & & \\
\hline & Cyanidin 3-glucoside & $8.12 \pm 0.42 \mathrm{mg}$ & $15.03 \pm 0.77 \mathrm{mg}$ \\
\hline & Peonidin 3-glucoside & $276 \pm 18.34 \mathrm{mg}$ & $311.11 \pm 15.87 \mathrm{mg}^{\star}$ \\
\hline \multirow[t]{3}{*}{3.} & Tocols & & \\
\hline & $\delta$-tocotrienol & $5.01 \pm 0.03 \mu \mathrm{g}$ & $5.21 \pm 0.27 \mu \mathrm{g}$ \\
\hline & $\gamma$-tocotrienol & $11.05 \pm 0.06 \mu \mathrm{g}$ & $11.82 \pm 0.60 \mu \mathrm{g}$ \\
\hline 4. & Gamma-Amino Butyric acid (GABA) & $4.4 \pm 0.23 \mu \mathrm{g}$ & $202.90 \pm 4.35 \mu \mathrm{g}^{\star * *}$ \\
\hline
\end{tabular}

Table 2A. Influence of selected variables (soaking time, soaking pH, and germination time) on GABA content of GBR-a Box-Behnken Design.

\begin{tabular}{|c|c|c|c|c|}
\hline Treatment & $\begin{array}{l}\text { Soaking } \\
\text { Time (h) }\end{array}$ & $\begin{array}{c}\text { Soaking } \\
\text { pH }\end{array}$ & $\begin{array}{c}\text { Germination } \\
\text { Time (h) }\end{array}$ & $\begin{array}{l}\text { GABA content } \\
\text { ( } \mathrm{mg} / \mathrm{g} \text { of } \mathrm{GBR})\end{array}$ \\
\hline 1 & 1 & 5 & 12 & 0.0039 \\
\hline 2 & 24 & 5 & 12 & 0.0538 \\
\hline 3 & 1 & 9 & 12 & 0.0040 \\
\hline 4 & 24 & 9 & 12 & 0.0590 \\
\hline 5 & 1 & 5 & 36 & 0.1557 \\
\hline 6 & 24 & 5 & 36 & 0.1666 \\
\hline 7 & 1 & 9 & 36 & 0.1575 \\
\hline 8 & 24 & 9 & 36 & 0.1731 \\
\hline 9 & 1 & 7 & 24 & 0.1024 \\
\hline 10 & 24 & 7 & 24 & 0.1255 \\
\hline 11 & 12 & 5 & 24 & 0.1133 \\
\hline 12 & 12 & 9 & 24 & 0.1370 \\
\hline 13 & 12 & 7 & 12 & 0.0292 \\
\hline 14 & 12 & 7 & 36 & 0.2029 \\
\hline 15 & 12 & 7 & 24 & 0.1411 \\
\hline 16 & 12 & 7 & 24 & 0.1510 \\
\hline 17 & 12 & 7 & 24 & 0.1243 \\
\hline 18 & 12 & 7 & 24 & 0.1330 \\
\hline 19 & 12 & 7 & 24 & 0.1329 \\
\hline 20 & 12 & 7 & 24 & 0.1441 \\
\hline
\end{tabular}

Table 3A. Statistical analysis of BBD using expert design.

\begin{tabular}{|c|c|c|c|c|c|c|}
\hline Source & Estimate & Sum of Squares & DF & Mean Square & F Value & $p$-value \\
\hline Intercept & 0.1353 & & 1 & & & \\
\hline Soaking time (A) & 0.0155 & 0.0024 & 1 & 0.0024 & 16.5724 & 0.0022 \\
\hline Soaking $\mathrm{pH}(\mathrm{B})$ & 0.0037 & 0.0001 & 1 & 0.0001 & 0.9610 & 0.3501 \\
\hline $\mathrm{AB}$ & 0.0012 & 0.0000 & 1 & 0.0000 & 0.0823 & 0.7800 \\
\hline $\mathrm{AC}$ & -0.0098 & 0.0008 & 1 & 0.0008 & 5.3230 & 0.0437 \\
\hline $\mathrm{BC}$ & 0.0004 & 0.0000 & 1 & 0.0000 & 0.0079 & 0.9311 \\
\hline $\mathrm{C}^{\wedge} 2$ & -0.0155 & 0.0007 & 1 & 0.0007 & 4.5847 & 0.0579 \\
\hline Model & & 0.0590 & 9 & 0.0066 & 45.4576 & $<0.0001$ \\
\hline Residual & & 0.0014 & 10 & 0.0001 & & \\
\hline Lack of Fit & & 0.0010 & 5 & 0.0002 & 2.1910 & 0.2048 \\
\hline Pure Error & & 0.0005 & 5 & 0.0001 & & \\
\hline
\end{tabular}

Note: Quadratic Equation 1 for GABA content $(\mathrm{mg} / \mathrm{g} \mathrm{GBR})=0.1353+0.0155(\mathrm{~A})+0.0037(\mathrm{~B})+0.0706(\mathrm{C})+0.0012(\mathrm{~A} \times \mathrm{B})-0.0098(\mathrm{~A} \times \mathrm{C})+0.0004(\mathrm{~B} \times \mathrm{C})-0.0176(\mathrm{~A})^{2}-0.0064$ $(B)^{2}-0.0155(C)^{2} \quad$ (1) The coefficient of determination $\left(R^{2}\right)$ value was 0.9761 . 
(a)

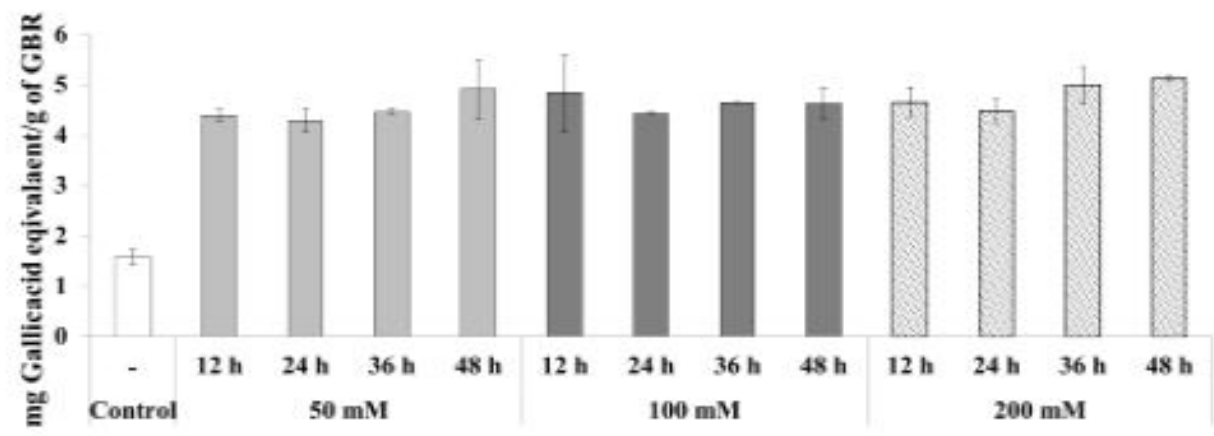

(b)

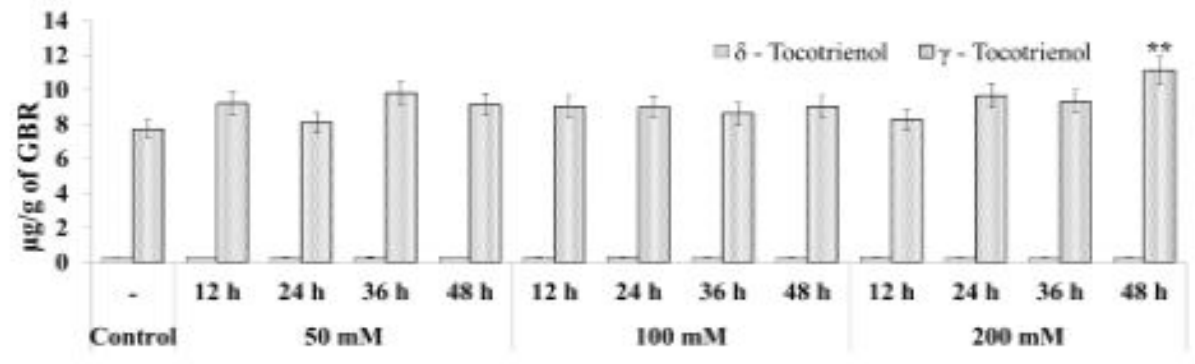

(c)

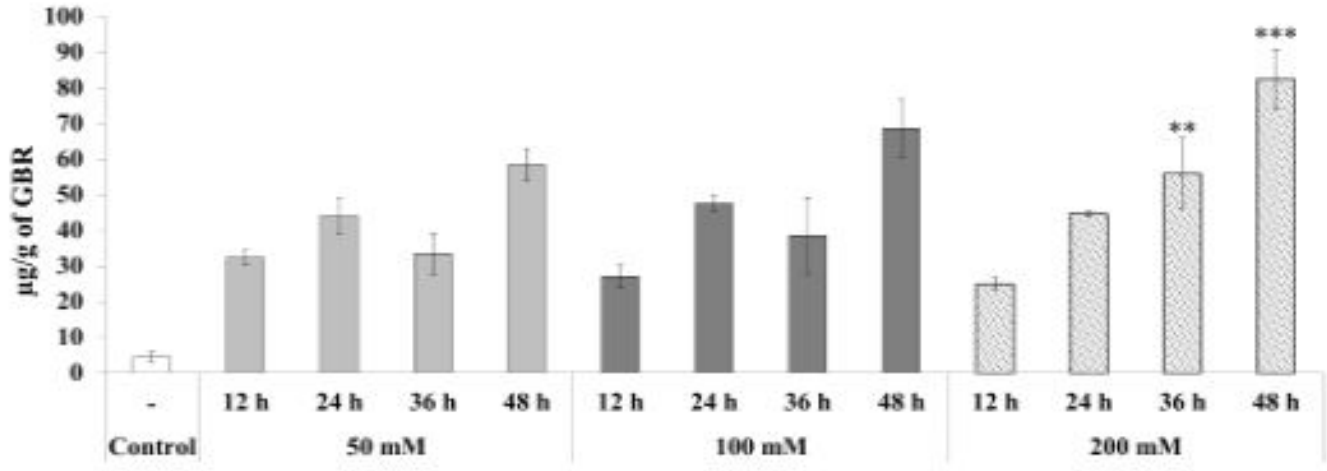

(d)

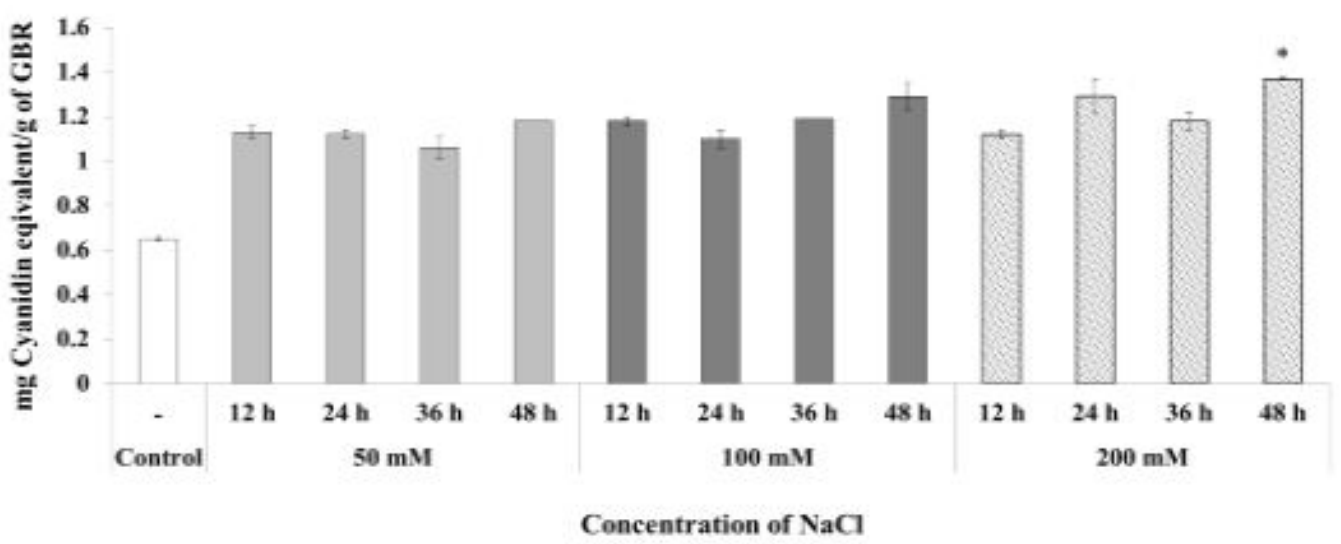

Figure 1A. The influence of salt concentration on phytochemical content of GBR. The changes in the (a) Phenolic acids (b) Tocols (c) GABA (d) Anthocyanins content after germination. The significant changes $\left({ }^{*} P \leq 0.05\right.$, ${ }^{* *} P \leq 0.005$, $\left.{ }^{* *} P \leq 0.001\right)$ were calculated using low concentration group $(50 \mathrm{mM} \mathrm{NaCl})$ as base value. 
(a)

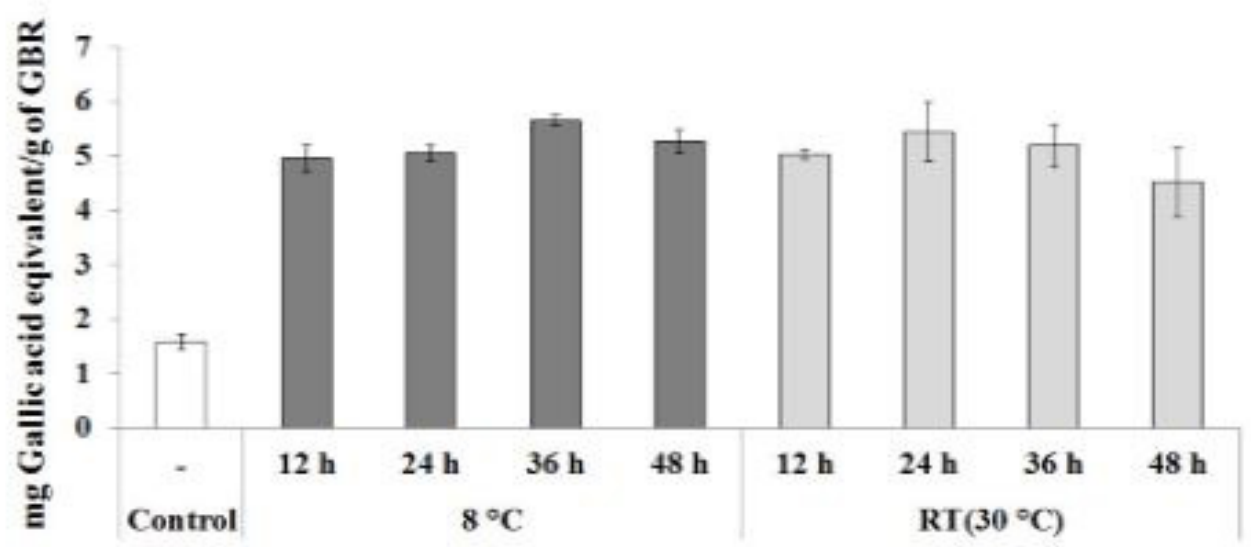

(b)

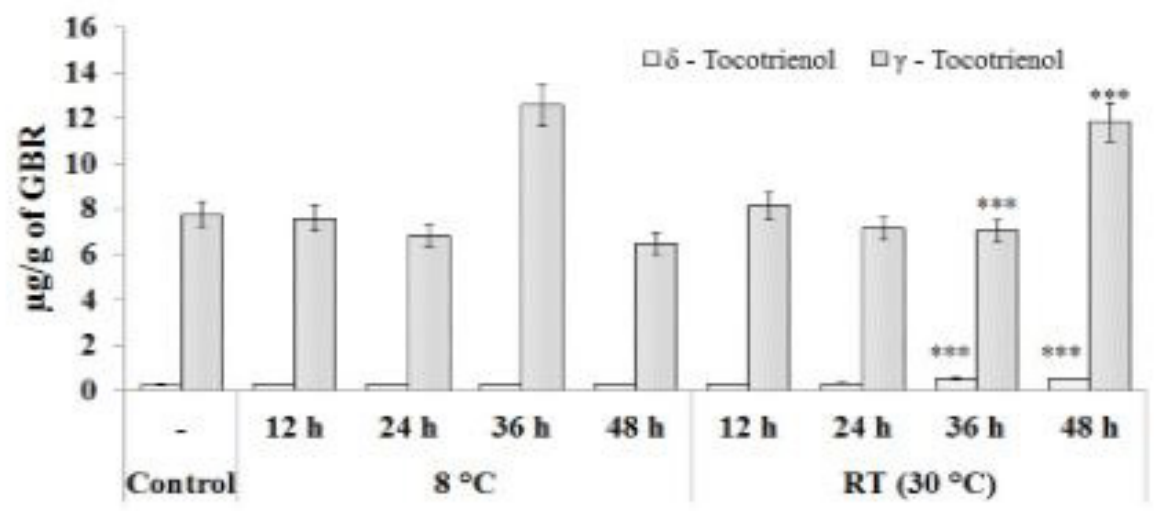

(c)

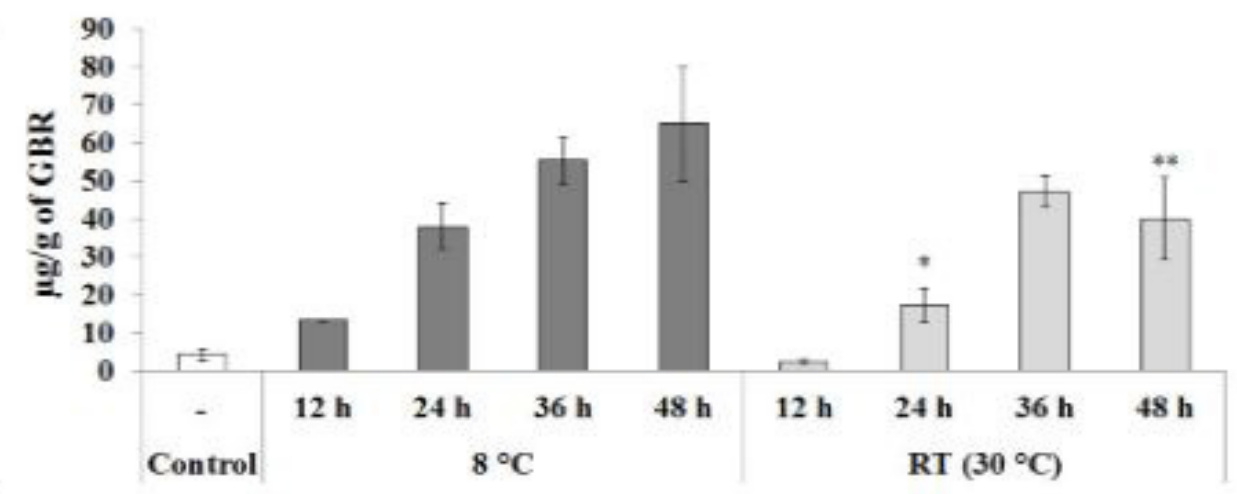

(d)

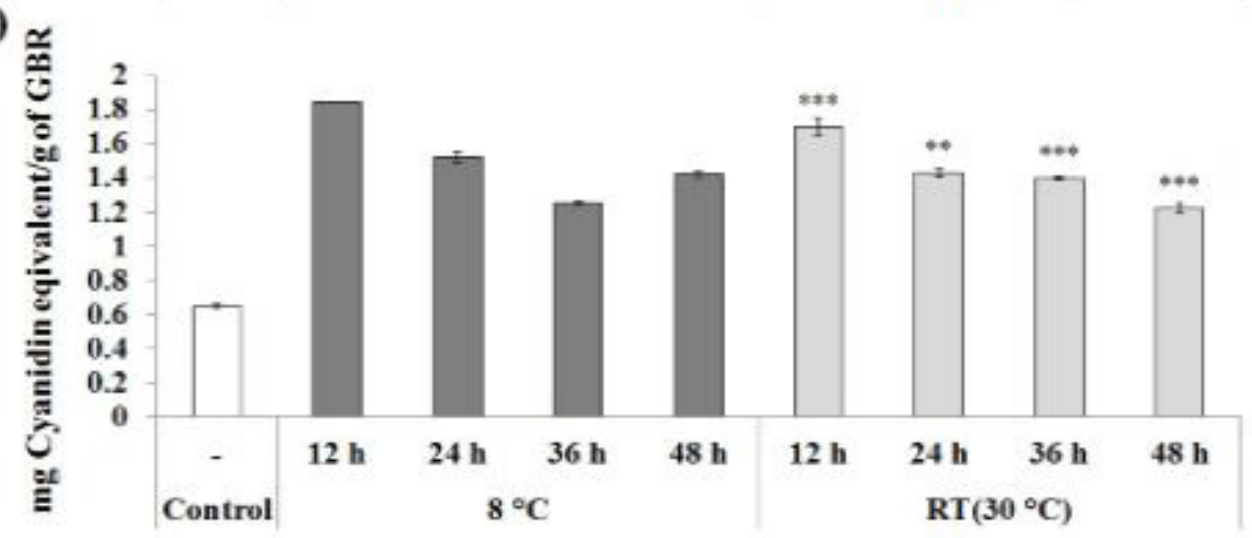

Temperature

Figure 2A. The influence of temperature on phytochemical content of GBR. The changes in the (a) Phenolic acids (b) Tocols (c) GABA (d) Anthocyanins content after germination. The significant $\left({ }^{\star} P \leq 0.05,{ }^{* *} P \leq 0.005,{ }^{* *} P \leq 0.001\right)$ changes were calculated using low concentration group $\left(8^{\circ} \mathrm{C}\right)$ as base value. 
(a)

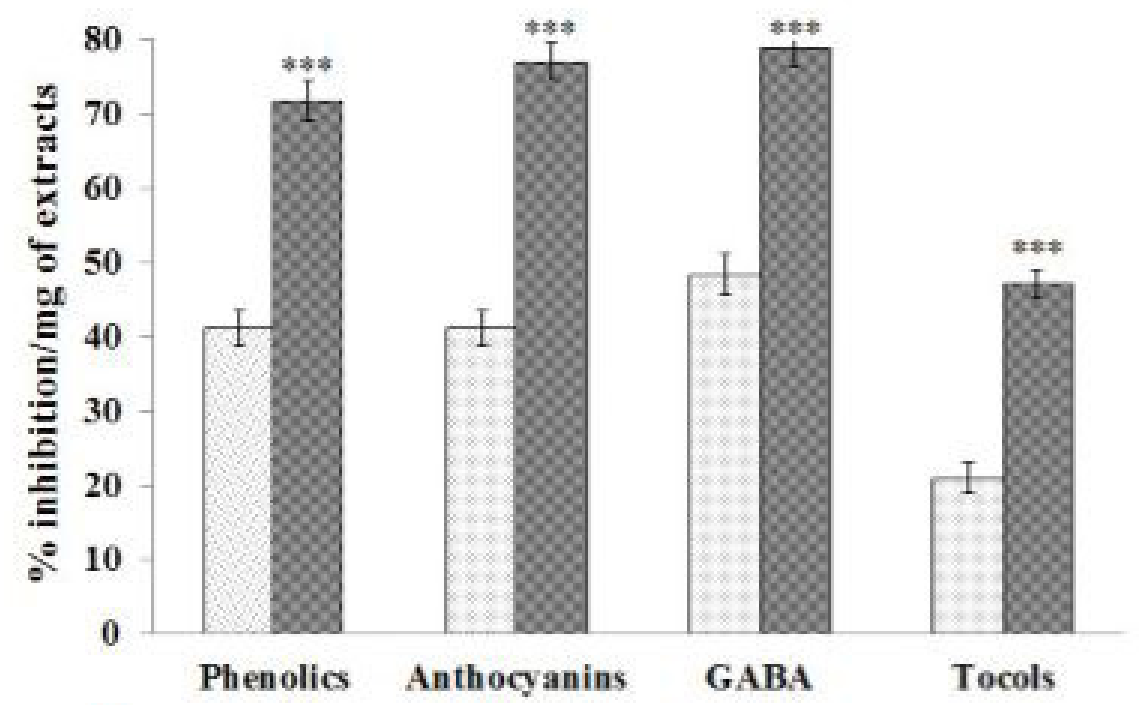

(b)
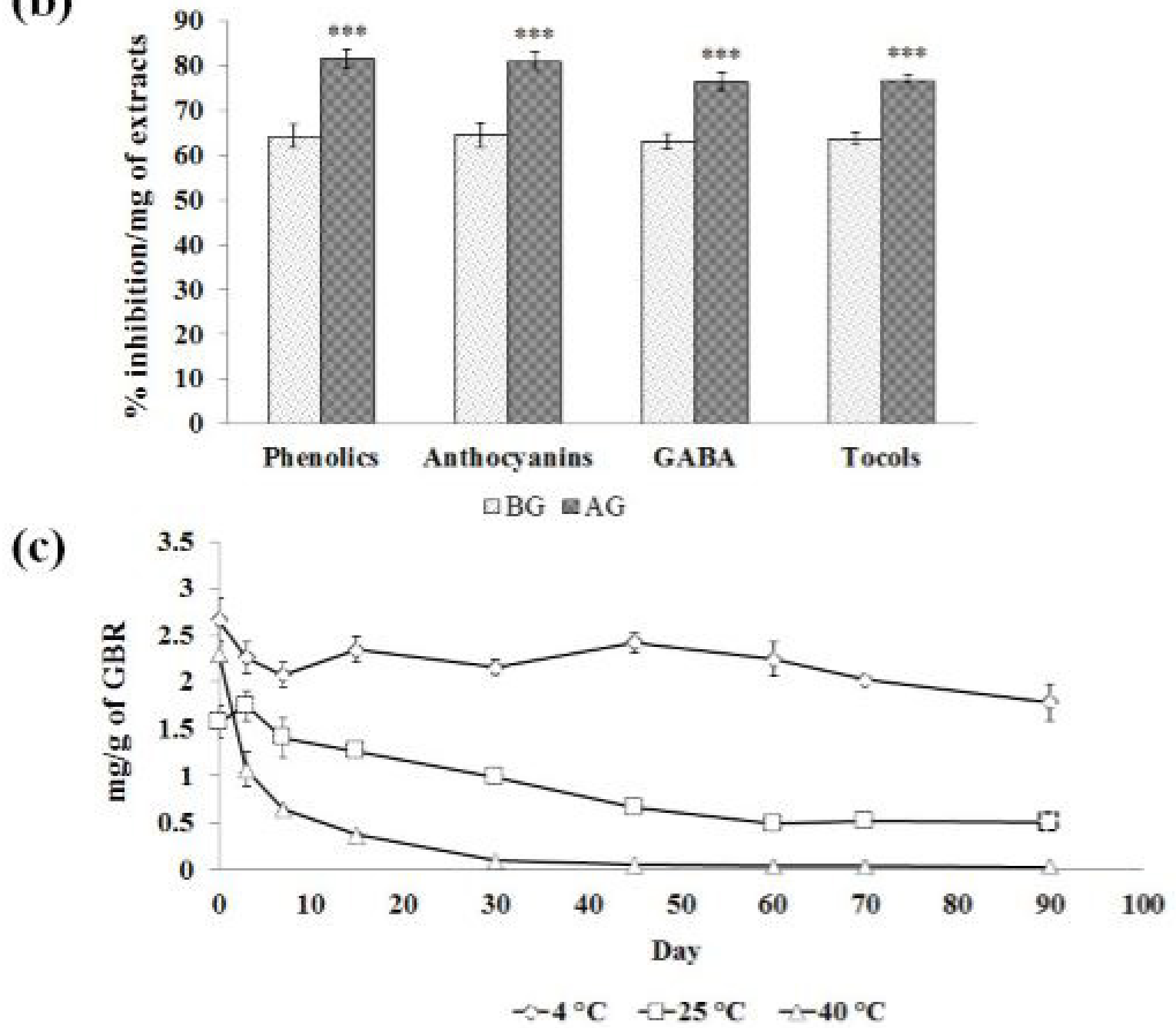

Figure 3A. The increase in the enzyme inhibiting property of black rice. (a) $\alpha$-amylase inhibition assay (b) $\alpha$-glucosidase inhibition assay. The significant changes $\left({ }^{* *} P \leq 0.001\right)$ were calculated by compared with non-germinated rice. BG: Before germination; AG: After germination. (c) The stability of GABA in germinated black rice at different temperature for 90 days. 